\title{
PENERAPAN ALGORITMA APRIORI UNTUK MENEMUKAN HUBUNGAN ANTARA JENIS KOMODITAS IMPORT DENGAN JUMLAH PERMINTAAN BULANAN
}

\author{
Tri Evendi ${ }^{1)}$, Rifda Faticha Alfa Aziza ${ }^{2)}$ \\ 1), 2) Fakultas Ilmu Komputer, Universitas AMIKOM Yogyakarta \\ Jl. Ring Road Utara, Condong Catur, Depok, Sleman, Yogyakarta 55281 \\ Email : evendyx@gmail.com ${ }^{l)}$,rifdafaticha@amikom.ac.id ${ }^{2)}$
}

\begin{abstract}
Abstrak
Impor merupakan salah satu komponen terpenting dari perdagangan negara selain ekspor, karena tanpa adanya impor maka negara tidak dapat memenuhi kebutuhan rakyatnya yang memang tidak diproduksi/ada di dalam negeri. Setiap impor pada suatu negara memiliki data yang didapatkan pada saat awal masuk dan juga nilai baik harga dan jumlah yang merupakan hasil transaksi perdagangan antarnegara. Akan tetapi, data-data tersebut belum diketahui hubungannya dengan data pada tiap bulan nya, untuk itu dibutuhkan sebuah metode untuk mengolahnya. Dengan penelitian ini, peneliti menggunakan sebuah metode Data Mining yaitu Association dengan Algoritma Apriori. Algoritma Apriori yang dimaksud merupakan teknik data mining untuk menemukan suatu aturan asosiatif berupa hubungan antara data komoditas impor dengan permintaan pada tiap bulannya. Data impor merupakan data yang terdiri dari kode HS, nama komoditas, nilai/value (US\$), berat $(\mathrm{kg})$ dan bulan. Nilai minimal support yang digunakan sebesar 50\% sedangkan nilai confidence ditetapkan sebesar $100 \%$ dan menghasilkan kesimpulan bahwa pada komoditi dengan HS Code 1022919 - 1022990 - 1051110 - 1061900 yang mana merupakan komoditi yang tiap bulannya terus diimport. Penelitian ini dilakukan menggunakan data impor menurut komoditi selama 9 bulan terakhir pada tahun 2018 dari badan pusat statistik.
\end{abstract}

Kata kunci: Impor, Data Mining, Komoditi, Association, Apriori algorithm, Nilai support dan confidence.

\section{Pendahuluan}

Impor merupakan salah satu komponen terpenting dari perdagangan negara selain ekspor, karena tanpa adanya impor maka negara tidak dapat memenuhi kebutuhan rakyatnya yang memang tidak diproduksi/ada di dalam negeri.

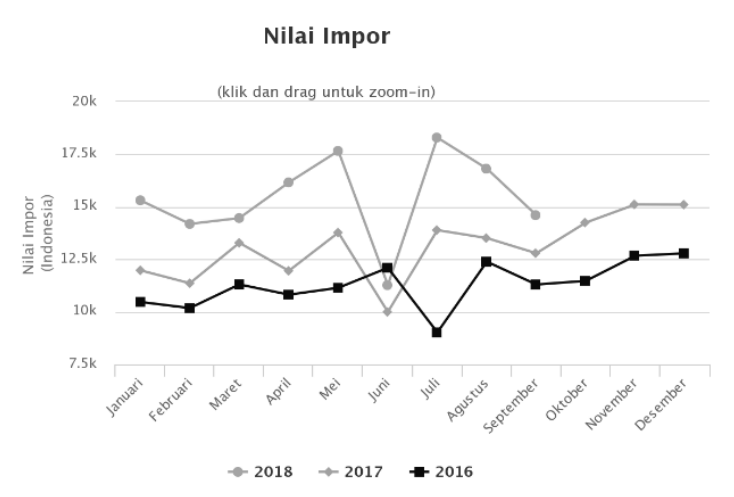

Gambar 1. Grafik Nilai Impor

Menurut Sutedi (2014:7) impor adalah proses memasukkan barang dari luar negeri kedalam negeri. Setiap impor pada sebuah negara memiliki data yang didapatkan pada saat awal masuk dan juga nilai harga yang merupakan hasil transaksi. Akan tetapi, data-data tersebut belum diketahui hubungannya dengan data pada tiap bulannya, untuk itu dibutuhkan sebuah metode untuk mengolahnya. Untuk itu, metode yang dipilih harus disesuaikan dengan tipe data yang sudah terkumpul, sehingga tujuan utama yaitu untuk menemukan hubungan antara data impor berdasarkan komoditas pada rentan waktu 9 bulan terakhir pada tahun 2018 dari badan pusat statistik (Agustina dan Reny, 2014).

\subsection{Rumusan Masalah}

Berdasarkan latar belakang yang telah diuraikan tersebut, maka dilakukan penelitian dengan judul "Penerapan Algoritma Apriori untuk Menemukan Hubungan antara Jenis Komoditas Impor dengan Jumlah Permintaan Impor Bulanan" untuk membantu melakukan klasifikasi terhadap pola permintaan komoditas impor pada tiap bulannya.

\subsection{Metodologi Penelitian}

Dalam sebuah penelitian, metodologi penelitian sangatlah dibutuhkan untuk menentukan tujuan sebenarnya dilakukannya penelitian yang sebernarnya (Kothari, 2004). Metodologi penelitian yang digunakan 
pada penelitian ini diuraikan pada bagian-bagian selanjutnya.

\subsubsection{Jenis Penelitian}

Jenis penelitian sangat berguna dalam menentukan arah dari penelitian yang dilakukan. Arah dari penelitian ini berkaitan langsung dengan tujuan yang ingin dicapai pada hasil penelitian nanti. Jenis penelitian yang digunakan adalah conclusion-oriented. Yaitu jenis penelitian yang memberikan kebebasan kepada peneliti untuk menentukan masalah serta mendesain ulang penyelidikan untuk mengkonseptualisasikan penelitian sesuai keinginan peneliti (Kothari, 2004).

\subsubsection{Metode Penelitian}

Metode penelitian merupakan semua metode yang digunakan oleh peneliti selama proses penelitian (Kothari, 2004). Penjelasan berikutnya mengenai metode penelitian akan dijelaskan pada bagian selanjutnya.

\subsubsection{Pengumpulan Data}

Data yang telah dikumpukan meliputi beberapa hal sebagai berikut:

1. Data yang digunakan pada penelitian ini merupakan data sekunder. Data Sekunder adalah data yang diperoleh atau dikumpulkan peneliti dari berbagai sumber yang telah ada, pada hal ini peneliti sebagai pihak kedua. Data sekunder diperoleh dari berbagai sumber seperti buku, laporan, jurnal, Biro Pusat Statistik (BPS), dan lain-lain sebagainya (Siyoto dan Sodik, 2015). Data diperoleh dari Badan Pusat Statistik, diakses melalui website dan diunduh dengan format dataset .xls.

2. Dataset yang digunakan pada penelitian ini merupakan data impor yang diambil dari website BPS. Data utamanya dikumpulkan berdasarkan dokumen-dokumen keterangan ekspor impor yang dihasilkan oleh Direktorat Jenderal Bea dan Cukai (Sumber Data BPS, 2018).

\subsubsection{Pengolahan Data}

Metode yang digunakan untuk mengolah data yaitu Algoritma Apriori. Prinsip yang digunakan pada penelitian ini adalah prinsip pemangkasan Apriori, dimana itemset yang tidak sering muncul tidak akan diujikan (Grand, 2018). Metode berjalan sesuai langkahlangkah berikut:

1. Pindai data untuk mendapatkan 1 itemset yang sering muncul.

2. Buat itemset kandidat $(\mathrm{k}+1)$ dari itemset $\mathrm{k}$ yang sering muncul.

3. Uji kandidat terhadap dataset.

4. Akhiri proses jika tidak ada himpunan yang sering muncul atau kandidat yang tidak dapat dibentuk lagi.

\subsection{Tinjauan Pustaka}

Beberapa penelitian yang telah dilakukan menggunakan data mining dengan algoritma apriori, sebagai berikut:
Penerapan Algoritma Apriori Untuk Menemukan Hubungan Data Murid Dengan Nilai Sekolah. Dalam penelitian ini penulis ingin mencari hubungan antara data murid dengan nilai sekolah. Hasil penelitian tersebut adalah nilai confidence terbesar diperoleh dari hubungan antara agama Kristen dengan nilai sekolah १77-82 sebesar 54,5\% (Grand, 2018).

Perancangan Aplikasi Data Mining Berbasis Web Dengan Algoritma Apriori Untuk Menentukan Produk Yang Berhubungan Pada Toko Buku Togamas Affandi. Dalam penelitian ini penulis ingin mencari hubungan antar produk yang saling berhubungan dan meningkatkan penjualan dengan pemberian diskon pada produk tertentu serta pembuatan perancangan dan implementasi dalam bentuk website. Hasil penelitian tersebut adalah didapatkan beberapa itemset yang memiliki confidence besar, salah satunya adalah hubungan anatar produk Maryamah Karpov dengan Edensor memiliki confidence 100\% (Chandra, 2016).

Penerapan Data Mining untuk Mengolah Data ImporEkspor Ikan dengan Menggunakan Metode Association Rule. Dalam penelitian ini penulis ingin membantu perusahaan dalam menentukan letak posisi penyimpanan produk impor dan ekspor berdasarkan tujuan negara. Hasil dari penelitian tersebut adalah data impor produk yang sering muncul dalam transaksi impor dengan confidence tertinggi $90 \%$ dan transaksi ekspor $88 \%$ (Puspasari, 2015).

\subsubsection{Data Mining}

Data mining adalah rangkaian proses untuk menggali nilai tambah berupa informasi yang belum terekplorasi dari sebuah basis data, melakukan ekplorasi dengan caracara tertentu untuk memanipulasi data menjadi informasi yang lebih berharga dengan cara mengektraksi dan mengenali pola penting dari basis data (Han dan Kamber, 2006).

Data mining, juga disebut knowledge discovery in database (KDD), yaitu kegiatan yang berupa pengumpulan, pemakaian data historis untuk menemukan keteraturan, pola atau hubungan dalam set data berukuran besar (Santosa, 2007).

Secara garis besar KDD dapat dijelaskan sebagai berikut. (1) Data Selection, Pemilihan (seleksi) data dari sekumpulan data operasional perlu dilakukan sebelum tahap penggalian informasi dalam KDD dimulai. Data hasil seleksi yang akan digunakan untuk proses data mining, disimpan dalam suatu berkas, terpisah dari basis data operasional. (2) Pre-processing/Cleaning, Sebelum proses data mining dapat dilaksanakan, perlu dilakukan proses cleaning pada data yang menjadi focus KDD. Proses cleaning mencakup antara lain membuang duplikasi data, memeriksa data yang inkonsisten, dan memperbaiki kesalahan pada data, seperti kesalahan cetak (tipografi). Juga dilakukan proses enrichment, yaitu proses "memperkaya" data yang sudah ada dengan data atau informasi lain yang relevan dan diperlukan untuk KDD, seperti data atau informasi eksternal. (3) Transformation, Coding adalah proses transformasi pada data yang telah dipilih, sehingga data tersebut sesuai 
untuk proses data mining. Proses coding dalam KDD merupakan proses kreatif dan sangat tergantung pada jenis atau pola informasi yang akan dicari dalam basis data. (4) Data Mining, Data mining merupakan proses mencari pola atau informasi menarik dalam data terpilih dengan menggunakan teknik atau metode tertentu. Pemilihan metode sangat bergantung pada tujuan dan proses KDD secara keseluruhan. (5) Interpretation / Evaluation, pola informasi yang dihasilkan dari proses data mining yang ditampilkan dalam bentuk yang mudah dimengerti oleh pihak yang berkepentingan. Tahap ini merupakan bagian dari proses KDD yang disebut interpretation. Tahap ini mencakup pemeriksaan apakah pola atau informasi yang ditemukan bertentangan dengan fakta atau hipotesis yang ada sebelumnya (Kusrini dan Luthfi, 2009).

\subsubsection{Association Rules Mining}

Analisis asosiasi atau association rules mining adalah teknik data mining untuk menemukan aturan asosiatif antara suatui kombinasi item (Kusrini dan Luthfi, 2009). Langkah-langkah yang dapat digunakan dalam data mining berupa:

(a) Support, adalah suatu ukuran yang menunjukkan seberapa besar tingkat dominasi suatu item atau itemset dari keseluruhan transaksi.

(b) Confidence, adalah suatu ukuran yang menunjukkan hubungan antar dua item secara conditional (berdasarkan suatu kondisi tertentu).

Metodologi dasar analisis asosiasi terbagi menjadi 2 tahap, yaitu melakukan analisa pada pola frekuensi tinggi (frequent pattern) dan selanjutnya proses pembentukan aturan asosiasi (Gunadi dan Sensuse, 2012).

\subsubsection{Algoritma Apriori}

Algoritma apriori adalah jenis aturan asosiasi pada data mining yang mana pada penelitian ini ditujukan untuk mencari kombinasi itemset yang mempunyai suatu nilai keseringan tertentu sesuai kriteria atau filter yang diinginkan (Kusrini dan Luthfi, 2009).

\subsubsection{HS Code}

Harmonized System (HS) adalah suatu daftar penggolongan barang yang dibuat secara sistematis dengan tujuan mempermudah penarifan, transaksi perdagangan, pengangkutan dan statistik yang telah diperbaiki dari sistem klasifikasi sebelumnya. Saat ini pengklasifikasian barang di Indonesia didasarkan kepada Harmonized System dan dituangkan ke dalam suatu daftar tarif yang disebut Buku Tarif Bea Masuk Indonesia (Kemendag, 2018).

\section{Pembahasan}

\subsection{Analisis Data}

Untuk menemukan hubungan data jenis komoditas dengan pola permintaan import tiap bulannya, maka metode yang diusulkan diterapkan pada bagian ini. Data yang diperoleh berupa data import dengan 20 kode HS dan nilai transaksi pada tiap bulannya. Data import selama sembilan bulan terakhir pada tahun 2018 diperlihatkan pada table dibawah ini :

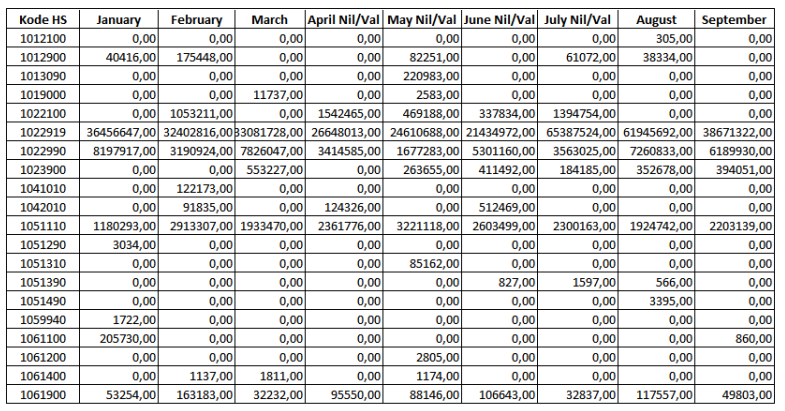

Gambar 2. Tabel Impor Menurut Komoditi Tahun 2018

\begin{tabular}{|l|l|}
\hline HS Code & \multicolumn{1}{|c|}{ Deskripsi HS } \\
\hline 1012100 & Horses, purebred breeding animals \\
\hline 1012900 & Live horses, other than purebred breeding animals \\
\hline 1013090 & Live asses, other than purebred breeding animals \\
\hline 1019000 & Live mules and hinnies \\
\hline 1022100 & Cattle, purebred breeding animals \\
\hline 1022919 & Live male cattle, not oxen, other than pure-bred breeding animals \\
\hline 1022990 & Live female cattle \\
\hline 1023900 & Live buffalo, other than pure-bred breeding animals \\
\hline 1041010 & Live sheep,pure-bred breeding animals \\
\hline 1042010 & Live goats, pure-bred breeding animals \\
\hline 1051110 & Live breeding fowls of the species Gallus domesticus, weighing $<=185 \mathrm{~g}$ \\
\hline 1051290 & Live turkey, weight $<=185 \mathrm{~g}$, other than breeding \\
\hline 1051310 & Live breeding ducklings, weight $<=185 \mathrm{~g}$ \\
\hline 1051390 & Live ducks, weight $<=185 \mathrm{~g}$, other than breeding \\
\hline 1051490 & Live geese, weight $<=185 \mathrm{~g}$, other than breeding \\
\hline 1059940 & Live geese, turkeys \& guinea fowls, weight $>185 \mathrm{~g}$, other than breeding \\
\hline 1061100 & Live primates, mammals \\
\hline 1061200 & Live whales, dolphin and porpoise,manatees and dugongs, seals, sea lion and walruses \\
\hline 1061400 & Live rabbits and hares, mammals \\
\hline 1061900 & Other live mammals \\
\hline & \\
\hline
\end{tabular}

Gambar 3. Tabel Deskripsi Kode HS

Dari data yang telah terkumpulkan, dibuatkan table baru untuk mempermudah pengujian. Tabel tersebut diperlihatkan pada gambar dibawah : 


\begin{tabular}{|c|c|c|c|c|c|}
\hline Bulan & HS Code & Bulan & HS Code & Bulan & HS Code \\
\hline \multirow[t]{8}{*}{ Januari } & 1012900 & \multirow[t]{8}{*}{ April } & 1022100 & \multirow[t]{8}{*}{ Juli } & 1012900 \\
\hline & 1022919 & & 1022919 & & 1022100 \\
\hline & 1022990 & & 1022990 & & 1022919 \\
\hline & 1051110 & & 1042010 & & 1022990 \\
\hline & \begin{tabular}{|l|}
1051290 \\
\end{tabular} & & 1051110 & & 1023900 \\
\hline & 1059940 & & 1061900 & & 1051110 \\
\hline & 1061100 & & & & 1051390 \\
\hline & 1061900 & & & & 1061900 \\
\hline \multirow[t]{12}{*}{ February } & 1012900 & \multirow[t]{12}{*}{ Mei } & 1012900 & \multirow[t]{12}{*}{ Agustus } & 1012100 \\
\hline & 1022100 & & 1013090 & & 1012900 \\
\hline & 1022919 & & 1019000 & & 1022919 \\
\hline & 1022990 & & 1022100 & & 1022990 \\
\hline & 1041010 & & 1022919 & & 1023900 \\
\hline & 1042010 & & 1022990 & & 1051110 \\
\hline & 1051110 & & 1023900 & & 1051390 \\
\hline & 1061400 & & 1051110 & & 1051490 \\
\hline & 1061900 & & 1051310 & & 1061900 \\
\hline & & & 1061200 & & \\
\hline & & & 1061400 & & \\
\hline & & & 1061900 & & \\
\hline \multirow[t]{8}{*}{ Maret } & 1019000 & \multirow[t]{8}{*}{ Juni } & 1022100 & \multirow[t]{8}{*}{ September } & 1022919 \\
\hline & 1022919 & & 1022919 & & 1022990 \\
\hline & 1022990 & & 1022990 & & 1023900 \\
\hline & 1023900 & & 1023900 & & 1051110 \\
\hline & \begin{tabular}{|l|}
1051110 \\
\end{tabular} & & 1042010 & & 1061100 \\
\hline & 1061400 & & 1051110 & & 1061900 \\
\hline & 1061900 & & 1051390 & & \\
\hline & & & 1061900 & & \\
\hline
\end{tabular}

Gambar 4. Tabel Pengujian

\subsection{Analisa Pola Frekuensi Tinggi}

Penelitian ini menggunakakan algoritma apriori untuk menemukan aturan asosiasi pola transaksi berdasarkan komoditi pada bulan Januari sampai September 2018 dari data badan pusat statistik dengan minimum support sebesar $50 \%$ dan minimum confidence sebesar $100 \%$. Sebelum melakukan pencarian pola transaksi, maka perlu dicari terlebih dahulu semua nama item serta menemukan support peritem, kemudian akan dicari kombinasi item yang memenuhi syarat minimum dari nilai support yang sudah ditentukan. Nilai support sebuah item dapat dicari dengan rumus :

\section{Rumus :}

Support(A) $\frac{\text { Jumlah_transaksi_komoditi_A }}{\sum \text { total_transaksi }}$.

Sedangkan nilai support 2 item diperoleh dengan rumus : Support(A-B)

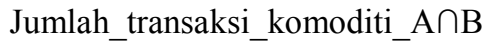

$$
\begin{aligned}
& \sum \text { total_transaksi }
\end{aligned}
$$

Adapun urutan langkah-langkah perhitungannya sebagai berikut:

\section{Iterasi 1:}

Menghitung support dan menentukan itemset yang memenuhi minimum support $(\mathrm{k}=1)$.

Langkah 1: Menghitung support untuk 1 itemset. Hasilnya seperti diperlihatkan oleh table 1 di bawah ini:

Tabel 1. Tabel Hasil Pengujian Support

\begin{tabular}{|c|c|c|c|}
\hline HS & Support & HS & Support \\
\hline 1012100 & $11 \%$ & 1051110 & $100 \%$ \\
\hline 1012900 & $56 \%$ & 1051290 & $11 \%$ \\
\hline 1013090 & $11 \%$ & 1051310 & $11 \%$ \\
\hline
\end{tabular}

\begin{tabular}{|l|c|c|c|}
\hline 1019000 & $22 \%$ & 1051390 & $33 \%$ \\
\hline 1022100 & $56 \%$ & 1051490 & $11 \%$ \\
\hline 1022919 & $100 \%$ & 1059940 & $11 \%$ \\
\hline 1022990 & $100 \%$ & 1061100 & $22 \%$ \\
\hline 1023900 & $67 \%$ & 1061200 & $11 \%$ \\
\hline 1041010 & $11 \%$ & 1061400 & $33 \%$ \\
\hline 1042010 & $33 \%$ & 1061900 & $100 \%$ \\
\hline
\end{tabular}

Langkah 2: Menentukan itemset yang memenuhi minimum support $50 \%$, kemudian item yang tidak memenuhi dieliminasi, sehingga menghasilkan tabel 2 di bawah ini:

Tabel 2. Tabel Hasil Pengujian Support

\begin{tabular}{|c|c|}
\hline HS & Support \\
\hline 1012900 & $56 \%$ \\
\hline 1022100 & $56 \%$ \\
\hline 1022919 & $100 \%$ \\
\hline 1022990 & $100 \%$ \\
\hline 1023900 & $67 \%$ \\
\hline 1051110 & $100 \%$ \\
\hline 1061900 & $100 \%$ \\
\hline
\end{tabular}

Iterasi 2:

Menghitung support dan menentukan itemset yang memenuhi minimum support $(\mathrm{k}=2)$.

Langkah 1: Menghitung support untuk 2 itemset. Hasilnya seperti diperlihatkan oleh tabel 3 di bawah ini:

Tabel 3. Tabel Hasil Pengujian Support

\begin{tabular}{|c|c|}
\hline HS & Support \\
\hline $1022919-1022990$ & $100 \%$ \\
\hline $1012100-1012900$ & $11 \%$ \\
\hline $1013090-1019000$ & $11 \%$ \\
\hline $1012900-1022100$ & $33 \%$ \\
\hline $1022100-1042010$ & $33 \%$ \\
\hline $1022100-1051110$ & $56 \%$ \\
\hline $1012900-1023900$ & $33 \%$ \\
\hline $1012900-1022919$ & $56 \%$ \\
\hline $1012900-1022990$ & $56 \%$ \\
\hline $1022919-1051110$ & $100 \%$ \\
\hline $1022990-1051110$ & $100 \%$ \\
\hline $1051110-1061900$ & $100 \%$ \\
\hline $1022919-1061900$ & $100 \%$ \\
\hline $1022990-1061900$ & $100 \%$ \\
\hline $1051110-1051390$ & $33 \%$ \\
\hline $1022100-1061900$ & $56 \%$ \\
\hline
\end{tabular}

Langkah 2: Menentukan itemset yang memenuhi minimum support $50 \%$, kemudian item yang tidak memenuhi dieliminasi, sehingga menghasilkan tabel 4 di bawah ini:

Tabel 4. Tabel Hasil Pengujian Support

\begin{tabular}{|c|c|}
\hline HS & Support \\
\hline $1022919-1022990$ & $100 \%$ \\
\hline $1022100-1051110$ & $56 \%$ \\
\hline $1012900-1022919$ & $56 \%$ \\
\hline $1012900-1022990$ & $56 \%$ \\
\hline
\end{tabular}




\begin{tabular}{|c|c|}
\hline $1022919-1051110$ & $100 \%$ \\
\hline $1022990-1051110$ & $100 \%$ \\
\hline $1051110-1061900$ & $100 \%$ \\
\hline $1022919-1061900$ & $100 \%$ \\
\hline $1022990-1061900$ & $100 \%$ \\
\hline $1022100-1061900$ & $56 \%$ \\
\hline
\end{tabular}

Iterasi 3:

Menghitung support dan menentukan itemset yang memenuhi minimum support $(\mathrm{k}=3)$

Langkah 1: Menghitung support untuk 3 itemset. Hasilnya seperti diperlihatkan oleh tabel 5 di bawah ini:

Tabel 5. Tabel Hasil Pengujian Support

\begin{tabular}{|c|c|}
\hline HS & Support \\
\hline $1012900-1022919-1022990$ & $56 \%$ \\
\hline $1022919-1022990-1051110$ & $100 \%$ \\
\hline $1022919-1022990-1061900$ & $100 \%$ \\
\hline $1022919-1022990-1023900$ & $67 \%$ \\
\hline $1012900-1013090-1019000$ & $11 \%$ \\
\hline $1022100-1022919-1022990$ & $56 \%$ \\
\hline $1041010-1042010-1051110$ & $11 \%$ \\
\hline $1023900-1051110-1061900$ & $56 \%$ \\
\hline $1023900-1051110-1051390$ & $33 \%$ \\
\hline $1051110-1051290-1059940$ & $11 \%$ \\
\hline $1012900-1051110-1061900$ & $56 \%$ \\
\hline $1022919-1051110-1061900$ & $100 \%$ \\
\hline $1022990-1051110-1061900$ & $100 \%$ \\
\hline $1051110-1061400-1061900$ & $33 \%$ \\
\hline $1012900-1022100-1022919$ & $33 \%$ \\
\hline $1012900-1022100-1022990$ & $33 \%$ \\
\hline
\end{tabular}

Langkah 2: Menentukan itemset yang memenuhi minimum support 50\%. Hasilnya seperti diperlihatkan oleh tabel 6 di bawah ini:

Tabel 6. Tabel Hasil Pengujian Support

\begin{tabular}{|c|c|}
\hline HS & Support \\
\hline $1012900-1022919-1022990$ & $56 \%$ \\
\hline $1022919-1022990-1051110$ & $100 \%$ \\
\hline $1022919-1022990-1061900$ & $100 \%$ \\
\hline $1022919-1022990-1023900$ & $67 \%$ \\
\hline $1022100-1022919-1022990$ & $56 \%$ \\
\hline $1023900-1051110-1061900$ & $56 \%$ \\
\hline $1012900-1051110-1061900$ & $56 \%$ \\
\hline $1022919-1051110-1061900$ & $100 \%$ \\
\hline $1022990-1051110-1061900$ & $100 \%$ \\
\hline
\end{tabular}

Iterasi 4:

Menghitung support dan menentukan itemset yang memenuhi minimum support $50 \%$ untuk 4 itemset $(\mathrm{k}=4)$

Hasilnya seperti diperlihatkan oleh tabel 7 di bawah ini:

Tabel 7. Tabel Hasil Pengujian Support

\begin{tabular}{|c|c|}
\hline HS & Support \\
\hline $1022919-1022990-1051110-1061900$ & $100 \%$ \\
\hline $1012900-1022919-1022990-1051110$ & $56 \%$ \\
\hline $1022100-1022919-1022990-1051110$ & $56 \%$ \\
\hline
\end{tabular}

\begin{tabular}{|l|l|}
\hline $1022919-1022990-1023900-1051110$ & $67 \%$ \\
\hline
\end{tabular}

Iterasi 5:

Menghitung support dan menentukan itemset yang memenuhi minimum support $50 \%$ untuk 5 itemset $(\mathrm{k}=5)$

Hasilnya seperti diperlihatkan oleh tabel 8 di bawah ini:

Tabel 8. Tabel Hasil Pengujian Support

\begin{tabular}{|c|c|}
\hline HS & Support \\
\hline $\begin{array}{c}1012900-1022919-1022990- \\
1051110-1061900\end{array}$ & $56 \%$ \\
\hline $\begin{array}{c}1022100-1022919-1022990- \\
1051110-1061900\end{array}$ & $56 \%$ \\
\hline $\begin{array}{c}1023900-1022919-1022990- \\
1051110-1061900\end{array}$ & $67 \%$ \\
\hline
\end{tabular}

Iterasi 6: Stop

Dikarenakan tidak ada itemset yang memenuhi minimum support $50 \%$, untuk 6 itemset $(\mathrm{k}=6)=0$.

\subsection{Pembentukan Pola Kombinasi dua items}

Untuk mencari aturan asosiasi penelitian ini menggunakan L2 dengan menetapkan minimum confidence sebesar $100 \%$. Untuk mencari nilai confidence dapat menggunakan rumus :

Confidence(A-B)

$$
\frac{\text { Jumlah_transaksi_komoditi_A A B }}{\sum \text { transaksi_A }}
$$

Diperoleh kombinasi aturan asosiasi pada tabel 9 di bawah ini:

Tabel 9. Tabel Hasil Pengujian Confidence

\begin{tabular}{|c|c|}
\hline HS & Confidence \\
\hline $1022919-1022990$ & $100 \%$ \\
\hline $1022100-1051110$ & $100 \%$ \\
\hline $1012900-1022919$ & $100 \%$ \\
\hline $1012900-1022990$ & $100 \%$ \\
\hline $1022919-1051110$ & $100 \%$ \\
\hline $1022990-1051110$ & $100 \%$ \\
\hline $1051110-1061900$ & $100 \%$ \\
\hline $1022919-1061900$ & $100 \%$ \\
\hline $1022990-1061900$ & $100 \%$ \\
\hline $1022100-1061900$ & $100 \%$ \\
\hline $1022990-1022919$ & $100 \%$ \\
\hline $1051110-1022100$ & $56 \%$ \\
\hline $1022919-1012900$ & $56 \%$ \\
\hline $1022990-1012900$ & $56 \%$ \\
\hline $1051110-1022919$ & $100 \%$ \\
\hline $1051110-1022990$ & $100 \%$ \\
\hline $1061900-1051110$ & $100 \%$ \\
\hline $1061900-1022919$ & $100 \%$ \\
\hline $1061900-1022990$ & $100 \%$ \\
\hline $1061900-1022100$ & $56 \%$ \\
\hline
\end{tabular}


Dari tabel 9 di atas yang memenuhi minimum support $50 \%$ dan confidence $100 \%$, diperlihatkan pada tabel 10 di bawah ini:

Tabel 10. Tabel Hasil Pengujian Confidence

\begin{tabular}{|c|c|c|}
\hline HS & Support & Confidence \\
\hline $1022919-1022990$ & $100 \%$ & $100 \%$ \\
\hline $1022100-1051110$ & $56 \%$ & $100 \%$ \\
\hline $1012900-1022919$ & $56 \%$ & $100 \%$ \\
\hline $1012900-1022990$ & $56 \%$ & $100 \%$ \\
\hline $1022919-1051110$ & $100 \%$ & $100 \%$ \\
\hline $1022990-1051110$ & $100 \%$ & $100 \%$ \\
\hline $1051110-1061900$ & $100 \%$ & $100 \%$ \\
\hline $1022919-1061900$ & $100 \%$ & $100 \%$ \\
\hline $1022990-1061900$ & $100 \%$ & $100 \%$ \\
\hline $1022100-1061900$ & $56 \%$ & $100 \%$ \\
\hline $1022990-1022919$ & $100 \%$ & $100 \%$ \\
\hline $1051110-1022919$ & $100 \%$ & $100 \%$ \\
\hline $1051110-1022990$ & $100 \%$ & $100 \%$ \\
\hline $1061900-1051110$ & $100 \%$ & $100 \%$ \\
\hline $1061900-1022919$ & $100 \%$ & $100 \%$ \\
\hline $1061900-1022990$ & $100 \%$ & $100 \%$ \\
\hline
\end{tabular}

\section{Kesimpulan}

Berdasarkan penelitian yang telah dilakukan, Algoritma Apriori dapat menemukan hubungan antara transaksi komoditi dengan komoditi lainnya pada rentang waktu 9 bulan terakhir. Dari penelitian dapat disimpulkan:

1. Transaksi import pada tahun 2018 di 9 bulan terakhir mengurangi pengurangan dari tiap bulannya.

2. Transaksi import pada bulan pertama ke bulan berikutnya, terdapat komoditas yang memiliki hubungan sangan kuat dengan komoditas lainnya (confidence $=100 \%$ ) sehingga pada tiap bulannya akan selalu ada transaksi yang sama dengan nilai/value (US\$) yang berbeda.

3. Komoditas dengan HS Code 1022919-10229901051110-1061900 merupakan komoditas yang tiap bulannya terus diimpor.

\subsection{Saran}

Mengingat keterbatasan dan kekurangan terhadap penelitian ini, baik pengetahuan, waktu maupun pemikiran, maka penulis dapat memberikan beberapa saran yang dapat dipakai sebagai acuan dalam penelitin yang akan datang, antara lain:

1. Lebih banyak data untuk mendapatkan hasil yang lebih objektif.

2. Menambahkan perhitungan lift agar nilai kepercayaan lebih akurat dan akuntable.

\section{Daftar Pustaka}

SUTEDI, ADRIAN SH. 2014. Hukum Ekspor Impor. Cetakan kesatu. Raih Asa Sukses (Penerbar Swadaya Grup): Jakarta Timur .
KOTHARI, C. R. 2004. Research Methodology: Methods \& Techniques New Delhi: New Age International $(P)$ Ltd..

GRAND. 2018. Penerapan Algoritma Apriori Untuk Menemukan Hubungan Data Murid Dengan Nilai Sekolah. STMIK Nusa Mandiri. IkraithInformatika, vol. 2, no. 1.

ANDREAS CHANDRA, BARKA. 2016. Perancangan Aplikasi Data Mining Berbasis Web Dengan Algoritma Apriori Untuk Menentukan Produk Yang Berhubungan Pada Toko Buku Togamas Affandi Teknik Informatika STMIK AMIKOM Yogyakarta.

DR. SANDU SIYOTO, SKM., M.KES \& M. ALI SODIK, M.A. 2015. Dasar Metodologi Penelitian. Editor: Ayup-Cetakan 1-Yogyakarta: Literasi Media Publishing.

HOX, J. J., \& BOEIJE, H. R. 2005. ata Collection, Primary vs. Secondary. Encyclopedia of Social Measurement, 5(1), 593-599.

SUMBER DATA.

2018. https://www.bps.go.id/subject/8/ekspor-impor.html diakses 12 November 2018.

PUSPASARI, R., BULURAN, I.Y. 2015. Penerapan Data Mining untuk Mengolah Data Impor-Ekspor Ikan dengan Menggunakan Metode Association Rule, in Proc Semnasteknomedia .

HAN, J.,\&KAMBER, M. 2006. Data Mining Concept and Tehniques. San Fransisco: Morgan Kauffman.

SANTOSA, B. 2007. Teknik Pemanfaatan Data untuk Keperluan Bisnis. Graha Ilmu.

KUSRINI, LUTHFI, E. T. 2009. Algoritma Data Mining. Penerbit ANDI.

GOLDIE GUNADI, DANA INDRA SENSUSE. 2012. Penerapan Metode Data Mining Market Basket Analysis Terhadap Data Penjualan Produk Buku Dengan Menggunakan Algoritma Apriori Dan Frequent Pattern Growth (Fp-Growth) : Studi Kasus Percetakan Pt. Gramedia. Telematika Mkom Vol.4 No.1.

PENGERTIAN HS CODE. 2018. http://djpen.kemendag.go.id/app_frontend/links/98hs-code diakses 12 November 2018.

KENNEDI TAMPUBOLON , HOGA SARAGIH , BOBBY REZA. 2013. Implementasi Data Mining Algoritma Apriori Pada Sistem Persediaan AlatAlat Kesehatan, Informasi dan Teknologi Ilmiah (INTI) Volume : I, Nomor : 1.

AGUSTINA, RENY. 2014. Pengaruh Ekspor, Impor, Nilai Tukar Rupiah, Dan Tingkat Inflasi Terhadap Cadangan Devisa Indonesia. Jurnal Wira Ekonomi Mikroskil Volume 4, Nomor 02. 